\title{
The Validity of Blended Learning-Based Laboratory Inquiry Learning
} Tools

\author{
Ezha Vandia Sulawanti*, Agus Ramdani, I Putu Artayasa \\ Magister of Science Education Program, Universitas Mataram, J1. Majapahit No.62, Mataram, \\ Indonesia, 83115
}

Corresponding Author e-mail: ezhavandiasulawanti96@gmail.com

Received: May 2021; Revised: June 2021; Published: June 2021

\begin{abstract}
The purpose of this study was to determine the validity of the blended learning-based laboratory inquiry learning device. This type of research includes research and development. The development research procedure carried out in the development of blended learning-based laboratory inquiry learning tools refers to the $4 \mathrm{D}$ development steps, namely define, design, develop and disseminate. The blended learning-based inquiry learning tool developed consists of a syllabus, lesson plans, LKPD, modules, and evaluation instruments. This study only focuses on content and construct validity which were validated by three experts. Based on the results of the validity analysis using the Aiken index and the reliability analysis using the percentage agreement, it was found that the blended learning-based laboratory inquiry learning tool developed had valid and reliable criteria.
\end{abstract}

Keywords: Learning Tools; Laboratory Inquiry; Blended Learning; Validity

How to Cite: Sulawanti, E., Ramdani, A., \& Artayasa, P. (2021). The Validity of Blended Learning-Based Laboratory Inquiry Learning Tools. Prisma Sains : Jurnal Pengkajian Ilmu dan Pembelajaran Matematika dan IPA IKIP Mataram, 9(1), 95-100. doi:https://doi.org/10.33394/j-ps.v9i1.3965

\section{INTRODUCTION}

Learning tools are one of the materials prepared by educators for students in carrying out learning activities (Ramdani, et al., 2020). Learning tools can be interpreted as a teaching aid used in the classroom to achieve the expected goals (Nwike \& ., 2013). The development of learning tools is one of the important points that must be considered by educators because learning tools are a form of preparation made by educators before carrying out the learning process. Learning tools are also very important because they serve as guidelines for implementing learning to produce good quality learning, including in learning biology.

Biology learning is one part of science learning that provides many opportunities and activities for students, where students not only learn facts, concepts, principles, laws but also learn how to obtain information, apply technology in science, and work scientifically (Khan , 2011). Biology is a field that examines empirical facts that exist in nature, so to study it must go through laboratory studies designed as miniature nature (Muzakkir, et al., 2015). The most common characteristic of learning biology is experimental learning. This means that learning biology will be better if it is supported by quality experiments (Khan, et al., 2011).

The Covid-19 pandemic that has attacked several countries, including Indonesia, has had a major impact on various sectors, one of which is education. In an effort to control the spread of the COVID-19 pandemic, in mid-March 2020, the government decided to temporarily suspend learning activities in schools. Schools are considered as one of the media that has the potential to expand the spread of COVID-19 because of the direct interaction between students, educators, and parents at a close distance. Therefore, temporary learning is carried out online, offline and the like until the specified time limit. Of course, this condition causes several changes in the learning process, including requiring students to study at home. 
Based on the results of field observations at two high schools in Mataram City, scientific literacy is only applied to the opening of learning. This causes the emergence of laziness and lack of curiosity of students towards the application of the concepts they have read and learned. Learning tools used such as syllabus, lesson plans, LKPD, modules and test instruments have not been able to facilitate students to develop and train students' biological science literacy skills. The device only develops cognitive aspects, without training literacy skills.

The results showed that the literacy skills of high school students were categorized as low with an average achievement of $40.5 \%$ (Fadilah et al, 2020). The current state of student scientific literacy in Indonesia is still relatively low when compared to other countries. One of the studies on scientific literacy skills that is used as a reference to determine the quality of education in world countries is through the Program for International Student Assessment (PISA) organized by the Organization for Economic Cooperation and Development (OECD). A total of more than 400,000 15-year-old students from 79 countries participated in PISA 2018. China became the country with the highest average achievement in this program for the science category with an average score of 590, on the other hand Indonesia only ranked 70 with an average achievement of 396 (OECD, 2018). This condition indicates/predicts that the scientific literacy of Indonesian students is still very low, including high school scientific literacy.

The COVID-19 pandemic is also an obstacle in carrying out activities that can support the needs of students, activities that are usually carried out in schools must be stopped, including conducting practicums / experiments that can train scientific literacy skills, developing innovation and creation. Students rarely even never do practical/experimental activities during a pandemic, this can make it increasingly difficult to train students to develop their scientific literacy skills (Yustina, et al., 2020).

The low quality of scientific literacy and skills possessed by students is caused by several deviations from the rules that have been set. One form of deviation in the implementation of learning is that students often manipulate data and tend to memorize and copy answers that already exist. This is because students are not given the freedom to design and implement the desired learning activities and do not take advantage of developing technology to attract students' interest in learning. Educators tend to limit the activities of students and often limited time in school becomes the biggest obstacle in achieving learning objectives (Schwicrhow, et al., 2016; Teiq, et al., 2020).

Laboratory inquiry utilizes the surrounding environment as a place for research. A wide environment will also provide broad opportunities for students to develop their abilities and skills because the research is not only limited to a room but outside the room can also be used as a research vehicle for students. Students can also use technology in their learning so that in addition to being skilled in learning, students are also technology literate. According to Khan et al., (2011) suggests that laboratory inquiry learning aims to familiarize students with working like a scientist because this learning model requires students to discover new knowledge, observe, classify and communicate in the learning process faced with problem situations in everyday life. -day (illstructured)

Blended learning is a formal education program in which a learner learns at least partially through content delivery and online teaching with some element of learner control over time, place, path, or pace (Hernandez et al, 2016). The integration of online learning environments and traditional learning environments can combine useful aspects of both methods. The online learning environment ensures flexibility and usefulness that cannot be found in the classroom environment while the offline learning environment (face to face) provides much needed social interaction for learning, where the role of educators is also very important in learning. Therefore, laboratory inquiry based on blended learning will support each other and is expected to have a positive effect on the quality of learning. With the use of 
the laboratory inquiry model based on blended learning, it is expected to increase literacy and self-regulated learning of Senior High Scholl students in Mataram.

From the results of research conducted by Sulawanti et.al (2019), it shows that the laboratory-based inquiry learning model can improve students' psychomotor abilities. Based on research conducted by Ramdani \& Badriah (2018). Laboratory-based inquiry learning models can improve the process and learning outcomes of students (Oktaviana, 2013). In addition, research conducted by Neneng (2017) suggests that the implementation of the laboratory-based inquiry learning model has an effect on students' conceptual changes, namely increasing students' conceptual understanding. According to Gunawan, et al (2021), blended learning-based inquiry has a good effect on learning outcomes on the concept of the digestive system.

The developed learning tools need to be validated. This validity is carried out so that the learning device is suitable for use in learning. This is in line with the opinion of Putra et al. (2018) which states that the learning tools need to be validated to ensure their quality. This is what underlies the researchers to conduct research with the aim of determining the validity of the blended learning-based laboratory inquiry learning device that was developed so that it can be applied in biology learning.

\section{METHOD}

This type of research includes research and development ( $R$ and $D)$. The procedure for developing blended learning-based laboratory inquiry learning tools refers to the 4D Thiagaran development steps (1974), namely define, design, develop and disseminate. The learning device validity test was carried out by three expert validators by filling out a validation sheet. The expert validation data were analyzed to determine the level of validity using the Aiken's V formula (1985). The level of validity is determined based on Table 1.

Table 1. Validity Level

\begin{tabular}{ll}
\hline Value Range & Category \\
\hline $\boldsymbol{V} \leq \mathbf{0 . 4}$ & Low Validity \\
$\mathbf{0 . 4}>\boldsymbol{V}<\mathbf{0 . 8}$ & Medium Validity \\
$\boldsymbol{V} \geq \mathbf{0 . 8}$ & High Validity \\
\hline
\end{tabular}

Furthermore, to measure the understanding between validators (inter rater reliability), it is analyzed using a percentage agreement. The results of the validation of learning tools are said to be reliable if the percentage agreement is $>75 \%$ (Borich, 1994). Learning devices are said to be suitable for use in learning, if the results of the analysis meet the category of high validity and reliable (Borich, 1994).

\section{RESULTS AND DISCUSSION}

The result of this development is a blended learning-based laboratory inquiry learning device. To fulfill the learning tools with valid and reliable categories that are suitable for use in learning, the steps for developing these learning tools refer to the stages of development of Thiagarajan (1974) namely Define, Design, Develop, Disseminate. The initial development stage of learning tools according to Thiagarajan (1974) is the define stage. The define stage aims to determine and define the needs in the learning process. At this stage, the data needed for research and development activities are collected (Ibrahim, et al., 2020). Based on the results of the analysis at the define stage in two public high schools in Mataram City, it shows that the learning tools developed by educators are not optimal and effective to support the needs of students, the student worksheet used is structured (cookbook recipe experiment) where practicum steps are available. in detail, clearly and structured (Suma, 2005). and modules using existing products so that students are lazy to think and do less scientific performance, so that students become less motivated to be literate and their abilities are not optimized 
The next stage is the design stage. The activities carried out at the design stage are the selection of the format and initial product design (Aryuntini et al., 2018). At this stage, the researcher designed the syllabus, lesson plans, student worksheet, modules, and evaluation instruments. The learning device designed is based on a laboratory inquiry model combined with blended learning. The results of the initial product design are used as the first draft of the learning device. The next stage is the development stage. Activities carried out at this stage are device validation by validators, device revision (draft II), limited trial, device revision (draft III), and final product. However, at this stage, the researcher limits it to the validation stage by experts. Validation aims to determine the level of validity and reliability of the developed learning tools. The results of the analysis of the validity and reliability of learning devices can be seen in the Table 2 .

Table 2. Learning tools validity

\begin{tabular}{llcccc}
\hline No & Learning Media & $\begin{array}{c}\text { Indeks } \\
\text { Aiken }\end{array}$ & Category & $\begin{array}{c}\text { Percentage } \\
\text { Agreement }\end{array}$ & Category \\
\hline 1 & Syllabus & 0.87 & Very Valid & 95.09 & Reliabel \\
2 & Lesson Plan & 0.83 & Very Valid & 94.72 & Reliabel \\
3 & Student Woksheet & 0.79 & Valid & 90.15 & Reliabel \\
4 & Teaching Material & 0.81 & Very Valid & 91.92 & Reliabel \\
5 & Scientific Literacy & 0.86 & Very Valid & 97.53 & Reliabel \\
& Instrument & & & & \\
\hline
\end{tabular}

Table 2 shows that the results of the assessment of the three validators of each component of the learning device such as the syllabus, lesson plans, module and test instrument have an average Aiken index of 0.80, which means that the components of the learning device have high validity, while the validity of the student worksheet is 0.79 which means that the learning device is valid. Calculation of agreement between validators found that all components of the learning tools developed had a percentage agreement $>75 \%$ or were included in the reliable category. The results of the agreement between the validators indicate that there is consistency between the validators. The results of the research conducted are in line with the research conducted by Ibrahim (2020) which shows that all learning tools validated by experts are classified as very valid.

The research of Ihsani et al. (2020) also showed that the average percentage score of the validity of learning tools from the three validators was $83.2 \%$ with very valid criteria. Inputs and suggestions from the validator are used as consideration for making revisions in order to improve the tools developed, so that learning tools are produced that are suitable for use in the field. The validator's input and suggestions for improving the syllabus are that the references used must be accountable, indicators and instruments are more adapted to the basic competencies (BC) because the BC bill is level C4. Some of the validator's suggestions for improving the lesson plan include: 1) The Operational Verbs (OV) used must be varied, 2). Online and offline learning scenarios are presented in writing, 3) the time when online and offline must be distinguished. Inputs and suggestions for improving the student worksheet include: 1) Use good and correct written language, namely paying attention to good and correct subject object predicate description Indonesian, 2) the problems presented must be more highlighted and, 3) in student worksheet more focus on skills development. Some suggestions for improving the module include: 1) use standard language and subject object predicate description, 2) pay attention to the space/distance between numbers and letters, the distance between one line and another, 3) teaching objectives must meet the audiens $\mathrm{A}$, audiens B, audiens C, audiens D component, 4) add instructions and directions for students, 5) there needs to be additional orders to make hypotheses and, 6) there is no need to include time allocation. Some inputs and suggestions for improving the biological science literacy test instrument and self-regulated learning include: 1) improve punctuation writing, 2) make simple sentences that are quickly understood by students, 3) pay attention to the format of 
writing answer choices, 4) create work instructions with simple sentences, 5) the number of statements made must be adjusted to the conditions of students, 6) use simple sentences so that students can easily understand them.

\section{CONCLUSION}

The blended learning-based laboratory inquiry learning device developed has high validity and reliability. This indicates that the learning tools developed are suitable for use in learning.

\section{RECOMMENDATION}

The resulting Blended Learning-Based Laboratory Inquiry Learning Tool can be an alternative learning model applied by teachers in teaching science subjects.

\section{ACKNOWLEDGMENT}

This research received no specific grant from any funding agency in the public,commercial, or not-for-profit sectors.

\section{REFERENCES}

Aiken, L. R. (1985). Three coefficients for analyzing the reliability and validity of ratings. Educational and psychological measurement, 45(1), 131-142.

Aryuntini, N., Astuti, I., \& Yuliana, Y. (2018). Development of Learning Media Based on VideoScribe to Improve Writing Skill for Descriptive Text of English Language Study. Journal of Education, Teaching and Learning, 3(2), 187-194.

Aryuntini, N., Astuti, I., \& Yuliana, Y. (2018). Development of Learning Media Based on VideoScribe to Improve Writing Skill for Descriptive Text of English Language Study. Journal of Education, Teaching and Learning, 3(2), 187-194.

Borich, G. D. (1994). Observation skills for effective teaching. New York.

Fadilah, F., Isti, S., Amarta, T. W. D., \& adi Prabowo, C. (2020). Analisis Kemampuan Literasi Sains Siswa Sma Pada Pembelajaran Biologi Menggunakan NOSLiT. Jurnal BIOEDUIN: Program Studi Pendidikan Biologi, 10(1), 27-34.

Gunawan, G., Jufri, A. W., Nisrina, N., Al-Idrus, A., Ramdani, A., \& Harjono, A. (2021, February). Guided inquiry blended learning tools (GI-BL) for school magnetic matter in junior high school to improve students' scientific literacy. In Journal of Physics: Conference Series (Vol. 1747, No. 1, p. 012034). IOP Publishing.

Ibrahim, I., Gunawan, G., \& Kosim, K. (2020). Validitas Perangkat Pembelajaran Fisika Berbasis Model Discovery dengan Pendekatan Konflik Kognitif. Jurnal Pijar Mipa, 15(3), 214-218.

Ihsani, N., Al Idrus, A., \& Jamaludin, J. (2020). Perangkat Pembelajaran Biologi Berbasis Masalah Terintegrasi Nilai-Nilai Islami Untuk Meningkatkan Penguasaan Konsep Peserta Didik. Jurnal Pijar Mipa, 15(2), 103-109.

Khan, M. S., Hussain, S., Ali, R., Majoka, M. I., \& Ramzan, M. (2011). Effect of inquiry method on achievement of students in chemistry at secondary level. International journal of academic research, 3(1), 955-959.

Muzakkir, M., Halim, A., \& Syukri, M. (2015). Pengaruh pelaksanaan praktikum inkuiri berbasis laboratorium virtual terhadap peningkatan motivasi dan kreativitas siswa. Jurnal Pendidikan Sains Indonesia (Indonesian Journal of Science Education), 3(1), 125-134.

Nwike, M. C., \& Catherine, O. (2013). Effects of use of instructional materials on students cognitive achievement in agricultural science. Journal of Educational and Social Research, 3(5), 103-103.

OECD. (2018). PISA 2018 Assesment and Analytical Framework. OECD 
Putra, A., Syarifuddin, H., \& Zulfah, Z. (2018). Validitas Lembar Kerja Peserta Didik Berbasis Penemuan Terbimbing dalam Upaya Meningkatkan Pemahaman Konsep dan Kemampuan Penalaran Matematis. Edumatika: Jurnal Riset Pendidikan Matematika, $1(2), 56-62$.

Ramdani, A., Jufri, A. W., \& Jamaluddin, J. (2020). Pengembangan Media Pembelajaran Berbasis Android pada Masa Pandemi Covid-19 untuk Meningkatkan Literasi Sains Peserta Didik. Jurnal Kependidikan: Jurnal Hasil Penelitian dan Kajian Kepustakaan di Bidang Pendidikan, Pengajaran dan Pembelajaran, 6(3), 433-440.

Ramdani, D., \& Badriah, L. (2018). Korelasi Antara Kemampuan Berpikir Kritis Dengan Hasil Belajar Siswa Melalui Model Pembelajaran Inkuiri Terbimbing Berbasis Blended Learning Pada Materi Sistem Respirasi Manusia. Bio Educatio, 3(2), 279473.

Schwichow, M., Croker, S., Zimmerman, C., Höffler, T., \& Härtig, H. (2016). Teaching the control-of-variables strategy: A meta-analysis. Developmental Review, 39, 37-63.

Sulawanti, E. V., Ramdani, A., Bahri, S., \& Merta, I. W. (2019). Pengaruh Penerapan Model Pembelajaran Inkuiri Berbasis Laboratorium Terhadap Kemampuan Psikomotorik Siswa. Jurnal Pijar MIPA, 14(3), 141-147.

Suma, K. (2005). Efektivitas kegiatan laboratorium konstruktivis dalam meningkatkan penguasaan konsep-konsep arus searah mahasiswa calon guru. Jurnal Pendidikan dan Pengajaran IKIP Negeri Singaraja, 38(2), 159-171.

Teig, N., Scherer, R., \& Kjærnsli, M. (2020). Identifying patterns of students' performance on simulated inquiry tasks using PISA 2015 log-file data. Journal of Research in Science Teaching, 57(9), 1400-1429.

Thiagarajan, S. (1974). Instructional development for training teachers of exceptional children: A sourcebook.

Yustina, Y., Halim, L., \& Mahadi, I. (2020). The Effect of'Fish Diversity'Book in Kampar District on the Learning Motivation and Obstacles of Kampar High School Students through Online Learning during the COVID-19 Period. Journal of Innovation in Educational and Cultural Research, 1(1), 7-14. 